\title{
Winning the Fight Against
}

Air Pollution in Ulaanbaatar

\section{Улаанбаатар хотын агаарын}

бохирдлын эсрэг тэмцэлд ялах нь 

Winning the Fight Against

Air Pollution in Ulaanbaatar

Улаанбаатар хотын агаарын

бохирдлын эсрэг тэмцэлд ялах нь 
(c) 2018 Asian Development Bank

6 ADB Avenue, Mandaluyong City, 1550 Metro Manila, Philippines

Tel +632 632 4444; Fax +6326362444

www.adb.org

Азийн хөгжлийн банк. 2018 он

АХБ-ны өргөн чөлөө 6, Мандалуён хот, Метро Манила 1550, Филиппин улс

Утас +63 2632 4444; Факс +63 26362444

www.adb.org

Some rights reserved. Published in 2018.

Зарим эрхийг хуулиар хамгаалсан. 2018 онд хэвлэв.

Publication Stock No. BRF189786-2

DOI: http://dx.doi.org/10.22617/BRF189786-2

Хэвлэлийн дугаap. BRF189786-2

DOI: http://dx.doi.org/10.22617/BRF189786-2

The views expressed in this publication are those of the authors and do not necessarily reflect the views and policies of the Asian Development Bank (ADB) or its Board of Governors or the governments they represent.

Энэхүү хэвлэлд илэрхийлсэн үзэл бодол нь зохиогчийнх бөгөөд Азийн хөгжлийн банк (АХБ), түүний Захирлуудын зөвлөлийн гишүүд болон тэдний төлөөлдөг улсын Засгийн газрын үзэл баримтлал, бодлогыг төлөөлөхгүй болно.

ADB does not guarantee the accuracy of the data included in this publication and accepts no responsibility for any consequence of their use. The mention of specific companies or products of manufacturers does not imply that they are endorsed or recommended by ADB in preference to others of a similar nature that are not mentioned.

Энэхүү хэвлэлд ашиглагдсан баримт өгөгдлийн үнэн зөвийг АХБ баталгаажуулахгүй бөгөөд тэдгээрийг ашигласны улмаас гарах аливаа үр дагаварт ямар нэгэн хариуцлага хүлээхгүй. Тодорхой компани эсвэл бүтээгдэхүүний тухай дурьдсан нь дурьдагдаагүй бусад ижил төрлийн компани ба бүтээгдэхүүнээс тэдгээрийг илүүд үзэж сурталчлах буюу санал болгох утга агуулаагүй болно.

By making any designation of or reference to a particular territory or geographic area, or by using the term "country" in this document, ADB does not intend to make any judgments as to the legal or other status of any territory or area.

Аливаа нэг улс орон эсвэл газар зүйн бүс нутгийг энэхүү хэвлэлд дурьдсан буюу нэрлэсэн, эсвэл “улс" гэсэн нэршлийг ашигласнаар, АХБ тухайн улс орон, бүс нутгийн хууль эрх зүйн болон бусад байдлын тухайд ямар нэгэн дүгнэлт, байр суурь илэрхийлээгүй болно.

This work is available under the Creative Commons Attribution 3.0 IGO license (CC BY 3.0 IGO)

https://creativecommons.org/licenses/by/3.0/igo/. By using the content of this publication, you agree to be bound by the terms of this license. For attribution, translations, adaptations, and permissions, please read the provisions and terms of use at https://www.adb.org/termsuse\#openaccess.

Энэ хэвлэх ажлыг Creative Commons Attribution 3.0 IGO license (CC BY 3.0 IGO)

https://creativecommons.org/licenses/by/3.0/igo/ лицензийн хүрээнд хийсэн болно. Энэхүү хэвлэлийг ашигласнаар та энэ лицензийн нөхцөлийг мөрдөн баримтлах үүргийг хүлээн зөвшөөрнө. Эх сурвалжийг олж тогтоох, орчуулах, хялбаршуулан хэрэглэх, зөвшөөрөл авах бол https://www.adb.org/terms-use\#ореnaccess холбоосоор орж нөхцөл журамтай танилцана уу.

This CC license does not apply to non-ADB copyright materials in this publication. If the material is attributed to another source, please contact the copyright owner or publisher of that source for permission to reproduce it. ADB cannot be held liable for any claims that arise as a result of your use of the material.

Энэхүу СС лиценз нь тус хэвлэлд дурдагдсан АХБ-ны бус зохиогчийн эрхтэй материалд үл хамаарна. Хэрэв аливаа материал өөр эх сурвалжтай холбоотой бол түүнийг дахин хэвлэх, хуулбарлах зөвшөөрлийг тухайн эх сурвалж бүхий зохиогчийн эрхийн эзэмшигч эсвэл хэвлэгч нарт хандан авна уу. Тухайн материалыг ашигласны улмаас гарах аливаа гомдол шаардлагыг АХБ үл хариуцна.

Please contact pubsmarketing@adb.org if you have questions or comments with respect to content, or if you wish to obtain copyright permission for your intended use that does not fall within these terms, or for permission to use the ADB logo.

Хэрэв танд агуулгын талаар асуух зүйл эсвэл санал байгаа бол, эсвэл та эдгээр нөхцөлөөс бусад зорилгоор ашиглахын тулд зохиогчийн эрхийн зөвшөөрөл авахыг хүсвэл, эсвэл АХБ-ны лого тэмдгийг ашиглах зөвшөөрөл хүсэх тохиолдолд pubsmarketing@adb.org гэсэн хаягаар холбогдоно уу.

Notes:

In this publication, “\$” refers to United States dollars

Corrigenda to ADB publications may be found at http://www.adb.org/publications/corrigenda.

Тайлбар:

Энэхүү нийтлэлд гарах “\$” тэмдэгт нь америк долларыг илэрхийлнэ.

АХБ-ны хэвлэлийн залруулгыг дараах хаягаар үзнэ үү: http://www.adb.org/publications/corrigenda

\section{Disclaimer for Translated Documents}

This document has been translated from English in order to reach a wider audience. While the Asian Development Bank (ADB) has made efforts to verify the accuracy of the translation, English is the working language of ADB and the English original of this document is the only authentic (that is, official and authoritative) text. Any citations must refer to the English original of this document.

Орчуулсан баримт бичгийн тайлбар

Энэхүу баримт бичгийг олон нийтэд хүртээмжтэй болгох зорилгоор Англи хэлнээс орчуулав. Азийн хөгжлийн банк (АХБ) нь орчуулгын үнэн зөвийг хянасан боловч АХБ-ны албан ёсны хэл нь Англи хэл тул энэхүу баримт бичгийн Англи хэл дээрх хувийг жинхэнэ (албан ёсны бүрэн эрхт) эх хувь гэж үзнэ. Энэхүу баримт бичгээс ишлэл татахдаа Англи хэл дээрх эх хувийг заавал дурдвал зохино. 


\section{Winning the Fight Against Air Pollution in Ulaanbaatar \\ Улаанбаатар хотын агаарын бохирдлын эсрэг тэмцэлд ялах нь}

\section{Abstract \\ Хураангуй}

- In winter, Ulaanbaatar is the coldest and most-polluted capital city in the world. The main cause of air pollution is the burning of raw coal for heating and cooking in ger areas, which accounts for $80 \%$ of the city's $\mathrm{PM}_{2.5}$ (inhalable particulate matter of less than 2.5 micrometers in diameter). Rapid urbanization, driven by fewer economic opportunities in rural areas of Mongolia, will continue to put pressure on air pollution in Ulaanbaatar.

Улаанбаатар хот нь өвлийн улиралд дэлхийн хамгийн хүйтэн бөгөөд бохирдол ихтэй нийслэлд тооцогддог. Агаарыг бохирдуулагч $\mathrm{PM}_{2.5}$ буюу нарийн ширхэглэгт тоосонцрын 80 хувь нь гэр хороололд түлэх түүхий нүүрснээс ялгарч байна. Хөдөө орон нутагт эдийн засгийн боломж хязгаарлагдмал байдгаас үүдэн хотжилт хурдацтай явагдсаар байгаа нь Улаанбаатар хотын агаарын бохирдлыг шийдвэрлэхэд хүндрэл учруулж байна.

- The impacts of air pollution in Ulaanbaatar are severe and have enormous socioeconomic costs. These impacts are, unsurprisingly, hardest felt by the city's vulnerable-the poor, the young, and the elderly. High exposure to pollution results in chronic illnesses, increased medical costs, and shorter life expectancy, and these effects in turn translate into productivity losses for the country.

Агаарын бохирдлын үр дагавар асар их бөгөөд нийгэм-эдийн засгийн өртөг зардал нь үлэмж өндөр юм. Эдгээр сөрөг нөлөө нь хүн амын эмзэг хэсэг болох ядуу иргэд, бага балчир хүүхдүүд болон ахмад настнуудад хамгийн хүндээр тусч байна. Бохирдолд их хэмжээгээр өртсөнөөс үүдэн гарах архаг өвчлөл, эрүүл мэндийн өндөр зардал, дундаж наслалт буурах зэрэг нь улс орны бүтээмжид сөргөөр нөлөөлдөг.

- Mongolia's challenge to reduce air pollution has unique aspects that require tailored solutions. However, there are important lessons from the successful experiences of other countries that can be adopted. These include improved data collection and monitoring, increased public awareness and government accountability, strengthened institutions, technology transfer, and financing mechanisms to support the transition to cleaner energy and technologies.

Агаарын бохирдлыг бууруулахад тулгарч буй бэрхшээл нь Монгол улсын хувьд нэлээд онцлог шинжтэй тул тэрхүү онцлогт нийцсэн шийдлүүдийг шаардана. Түүнчлэн, агаарын бохирдлыг амжилттай бууруулсан улс орнуудын туршлага, сургамжаас суралцаж оновчтойг нь авч хэрэгжүүлэх хэрэгтэй. Тухайлбал, өгөгдөл мэдээлэл цуглуулж, хяналт тавих асуудлыг сайжруулах, иргэдийн мэдлэг ойлголтыг дээшлүүлэх, төрийн албаны хариуцлагыг өндөржүүлэх, институцийг бэхжүүлэх, технологи нэвтрүүлэх, цэвэр эрчим хүчийг ашиглахад дэмжлэг үзүүлэх санхүүжилтийн оновчтой механизмыг бий болгох зэрэг өөрчлөлтийг дэмжсэн арга шийдлүүдээс суралцах нь чухал. 


\section{Observations and Suggestions}

\section{Ажиглалт ба санал}

- Reducing pollution levels in Ulaanbaatar will be an extended process requiring a mix of short- and long-term actions. The Government of Mongolia has reinvigorated the country's commitment to the issue through a number of recent actions and policy announcements.

Улаанбаатар хотын бохирдлын хэмжээг бууруулах нь богино болон урт хугацааны зорилтот арга хэмжээнээс бүрдсэн, цаг хугацаа шаардсан үйл явц болно. Монгол Улсын Засгийн газраас сүүлийн үед авч хэрэгжүүлж буй арга хэмжээнүүд нь орчны бохирдлын эсрэг Монгол улс шийдэмгий тэмцэж буйг харуулж байна.

- This policy note presents recommendations that can crystallize the existing policy momentum into a long-term, institutionalized framework for sustainable solutions to reduce air pollution in Ulaanbaatar. In the shorter term, policies should focus on improving institutional management, increasing information flows, and implementing preventive measures that can be enacted quickly and with visible results. In the longer term, it is recommended to adopt reforms to ensure the sustainability of efforts to reduce pollution, such as curbing rural-urban migration by creating livelihood opportunities in rural areas, and redeveloping urban areas in line with environmental targets.

Улаанбаатар хотын агаарын бохирдлыг бууруулахаар одоо авч хэрэгжүүлж буй бодлогын алхмуудыг урт хугацаанд хадгалагдах тогтвортой шийдлүүд бүхий институцийн орчин болгон бэхжүүлэх зөвлөмжүүдийг энэхүү баримт бичигт тусгалаа. Бодлогын богино хугацааны тэргүүлэх чиглэлд институцийн засаглалыг бэхжүүлэх, мэдээллийн урсгалыг эрчимжүүлэх, богино хугацаанд бодитой үр дүн авчрахуйц урьдчилан сэргийлэх арга хэмжээнүүдийг авах зэргийг тусгах нь оновчтой. Харин урт хугацаандаа хөдөө орон нутагт амьдран суух боломжийг нэмэгдүүлэх, байгаль орчны зорилтуудад нийцүүлэн хот суурин газруудыг оновчтойгоор дахин төлөвлөх зэргээр хөдөөгөөс хот руу шилжих хөдөлгөөний хурдыг сааруулан, бохирдлыг бууруулах хүчин чармайлтын тогтвортой байдлыг хангах шинэчлэлийг хийх нь чухал. 


\section{INTRODUCTION}

1. Air pollution is widely viewed as a common cost of industrialization. Continued exposure to high levels of pollution has severe socioeconomic impacts ranging from chronic illness to reduced employment opportunities and loss of income. Addressing these issues requires concerted efforts across society, underpinned by clear and specific reforms and policy actions.

2. Air pollution in Ulaanbaatar has escalated to alarming levels. A lack of urban planning, particularly amid rapid migration to the city from rural areas, is at the core of the problem. The impact goes beyond harmful and insidious health effects and has become a significant development challenge. In 2013, welfare costs from exposure to air pollution in Mongolia were equivalent to $6.9 \%$ of the country's annual gross domestic product.'

3. As the population of Ulaanbaatar is expected to rise to 1.9 million by 2025 , and to 2.7 million by 2050, pollution and its associated costs will severely worsen, unless strategic actions are urgently adopted. By reviewing the main factors behind air pollution in the city, this policy note aims to make relevant policy recommendations to develop a framework to combat air pollution.

\section{AIR POLLUTION IN ULAANBAATAR AND THE POLICY CHALLENGE}

4. In winter, Ulaanbaatar is the coldest and most-polluted capital city in the world. At this time of year, the average concentration of $\mathrm{PM}_{2.5}$ reaches 40 times recommended annual guidelines, but daily levels can be as much as 80 times higher than recommended. ${ }^{2}$ Man-made and natural causes contribute to high pollution in Mongolia's cities. An increase in the frequency of $d z u d s$ (harsh winters) and summer droughts has worsened conditions for herders in rural areas. This has led to migration to cities and has helped increase Ulaanbaatar's population to 1.5 million people, a rise of more than $30 \%$ since 2007 . Inadequate urban planning to accommodate these new residents has led to the emergence of vast periurban areas named ger areas, now hosting $60 \%$ of the total city population or about 800,000 people.

5. Ger areas lack adequate public services, such as water, sanitation, public transport, and heat and power supply. Residents of these areas rely on raw coal (or, in the poorest households, solid waste) for heating and cooking. This heating system alone accounts for $80 \%$ of $\mathrm{PM}_{2.5}$ during the winter months in Ulaanbaatar. The remaining $20 \%$ stems from archaic coal-fired boilers used only for heating in ger areas, traffic congestion, outdated combined heat and power plants, and resuspension of dust from unpaved roads and coal ash. Furthermore, the phenomenon of winter temperature inversion, i.e., cold air layering

\footnotetext{
World Bank. 2016. The Cost of Air Pollution: Strengthening the Economic Case for Action. Washington, DC.

${ }^{2} \mathrm{PM}_{2.5}$ refers to ambient concentrations of inhalable particulate matter of less than 2.5 micrometers in diameter.
} 


\section{Observations and Suggestions}

\section{Ажиглалт ба санал}

above warm air near the ground, traps air in the valley in which Ulaanbaatar is located, preventing pollution from dispersing.

6. Air pollution has the greatest impact on Ulaanbaatar's vulnerable. Poor families are especially exposed as they are often malnourished, cannot afford medical care, and are more likely to live and work in the most-polluted areas of the city. Children are particularly affected by pollution, suffering from reduced fetal growth, preterm birth, pneumonia, impaired brain development, and reduced lung function that can lead to acute and chronic respiratory diseases. A study conducted in 2018 by the United Nations International Children's Emergency Fund (UNICEF) shows a 350\% rise in fetal deaths in winter compared to summer, using 2009-2011 data. ${ }^{3}$ Through its impact on health, often from the time of a person's birth, air pollution hampers labor productivity and income opportunities through illness, disability, and premature death. The UNICEF study warns that treating children for diseases induced by air pollution would lead to increased costs of MNT24.8 billion ( $\$ 9.8$ million) across 2017-2025 in Ulaanbaatar alone: adding indirect costs almost doubles this figure.

7. The problem created by poor urban planning in Ulaanbaatar has been compounded by a fragmented policy response. For example, emergency policies to minimize air pollution caused by burning raw coal for heating-such as the provision of cleaner coal-were initiated under pilots too small to show results, then discontinued. The same scenario has occurred with subsidized electricity tariffs; a policy action that, if not coupled with financial support to buy electric stoves, will not incentivize people to shift away from burning coal. Greater reliance on renewable energy is constrained by the absence of an agreement on a long-term feed-in tariff and limited technical capacity. Similarly, the provision of more environmentfriendly heating fuel and stoves has not been pursued due to unsuccessful pilot programs, despite strong evidence of the efficacy of such a strategy in curbing pollution.

8. Some progress has, however, been made through new Mongolian legislation. The Law on Air sets out several important measures, including the subsidizing of electricity used by households for heating purposes and the banning of raw coal. This legislation mandated the Prime Minister to establish the National Committee for the Reduction of Air Pollution (the National Committee) and enabled the Government of Mongolia to establish the Clean Air Fund. The Law on Fees for Air Pollutants introduced a system for charging fees on air pollution. These initiatives aimed to set out a framework to establish emissions thresholds and to monitor and fine polluters. However, weak policy implementation, frequent policy changes, the growing severity of air pollution, and the economic downturn in 2015-2016 resulted in public demonstrations demanding stronger government action and accountability on pollutionreduction efforts. The government responded by renewing the National Committee in November 2016. This committee oversaw the preparation of an MNT9.8 trillion ( $\$ 4.1$ billion) National Program for Reducing Air and Environmental Pollution 2017-2025, approved in March 2017. The formulation of a

\footnotetext{
3 UNICEF. 2018. Mongolia's Air Pollution Crisis: A Call to Action to Protect Children's Health. Ulaanbaatar.
} 


\section{Winning the Fight Against Air Pollution in Ulaanbaatar Улаанбаатар хотын агаарын бохирдлын эсрэг тэмцэлд ялах нь}

comprehensive program to reduce pollution in Mongolia is a solid start, but greater efforts are needed to ensure the implementation and enforcement of the program's relevant actions. In this regard, a longterm government commitment, irrespective of the political cycle, is a must.

\section{EXPERIENCES FROM OTHER COUNTRIES}

9. International experience shows that pollution control needs specific policy actions and strong government engagement to succeed. Public awareness and social pressure are also important in ensuring government accountability. For instance, in 1970, nongovernment organizations with an environmental orientation played a key role in the establishment of the Environmental Protection Agency and the passing of the Clean Air Act in the United States, both of which have been critical in reducing air pollution in the United States.

10. Some countries have successfully developed legislation that disincentivizes polluting behavior, such as the use of high-polluting vehicles and fuels. International experience shows that these measures are only effective when affordable alternatives are available and when social awareness is strong enough to sustain the required behavioral change, supported by a consistent government commitment. In Ireland, the "Smoky Coal Ban" was introduced to Dublin in 1990 and has since averted an estimated 8,000 premature deaths. ${ }^{4}$ Its success resulted in the Government of Ireland extending the ban on burning smoky coal and other prohibited fuels to defined low-smoke zones. The ban was further extended nationwide in December 2017, becoming effective in 2019 to enable coal distributors to sell off existing stocks.

11. Germany provides a good example of the use of technology to curb the emission of dangerous air pollutants. The country has a clean power plant fleet and therefore, despite a relatively high reliance on energy produced by fossil fuels, is a leader in the fight against air pollution. Germany and the United Kingdom introduced strict fuel control strategies in the 1980 s (with unleaded and ultra-low sulfur fuels) and saw major reductions in air pollution by the transport sector as a result.

12. The approach adopted by the People's Republic of China - an approach characterized by decisive government action triggered by growing social pressure-yields interesting lessons. A major investment was made in understanding pollution issues through scientific analysis, underpinned by the design of robust and targeted measures. The analysis conducted by authorities in the People's Republic of China suggested the need for costly but effective measures embedded in an ambitious national action plan. These measures included setting ceilings on the use of coal and capping production levels in key national industries, such as steel production. Government commitment and leadership was key in pursuing the

\footnotetext{
${ }^{4}$ Government of Ireland. Department of Communications, Climate Action \& Environment. Smoky Coal Ban. https://www. dccae.gov.ie/en-ie/environment/topics/air-quality/smoky-coal-ban/Pages/default.aspx (accessed September 2018).
} 


\section{Observations and Suggestions}

\section{Ажиглалт ба санал}

proposed policies. Efforts culminated in March 2018, with the establishment of a 'super' environment ministry to provide greater institutional support that will help sustain the measures and further realize their initial promising results.

\section{RECOMMENDATIONS}

13. While lessons from other countries are valuable for Mongolia, the high rate of rural-urban migration and extremely harsh winters create a unique challenge for the country and require a tailored approach. Solutions will demand concerted and sustained efforts by multiple stakeholders - the general public, civil society, the private sector, and development partners-led by strong government accountability for, and ownership of, pollution issues. Short-term actions through to 2020 should prioritize reducing the major drivers of air pollution and mitigating health effects related to pollution. Longer-term measures through to 2030 should aim to improve air quality in Ulaanbaatar on a sustainable basis. Designing, planning, and budgeting for the short- and long-term policies is challenging, but success will result in a significant and sustained boost to Mongolia's productivity and lay the foundations for dynamic urban centers to drive future economic growth. The Government of Mongolia has taken many steps in the right direction, most notably demonstrated by its commitment to implement recommendations from the Asian Development Bank to improve the quality of fuel in Ulaanbaatar and strengthen the country's regulatory framework on air pollution. ${ }^{5}$ In addition, many development partners are providing important support to the resolution of this problem. Despite this progress, more can be done and the following recommendations are made with this in mind.

\section{a. Short-Term Policy Actions}

14. Create an initiative driven by multiple stakeholders to oversee policy actions on pollution reduction. The National Committee for the Reduction of Air Pollution needs to have the power to push through key measures to combat air pollution in Ulaanbaatar. Because reducing air pollution will require concerted and consistent effort over many years, political leaders must reach a cross-party consensus on the actions required to do so. Such a consensus will ensure a sustainable approach to fighting air pollution; an approach that can withstand changes of government or short-term political motives. To that end, the government should create a politically independent secretariat for the National Committee, which would be entrusted with administering, coordinating, and overseeing the implementation of the National Committee's decisions. To ensure policy coherence, the secretariat should also be charged with preserving the institutional memory of air pollution reduction efforts. The secretariat's participants should include policymakers, legislators, representatives of civil society, journalists, and members of the

\footnotetext{
${ }^{5}$ Asian Development Bank. 2018. Ulaanbaatar Air Quality Improvement Program. Manila.
} 


\section{Winning the Fight Against Air Pollution in Ulaanbaatar Улаанбаатар хотын агаарын бохирдлын эсрэг тэмцэлд ялах нь}

private sector, ensuring genuine commitment and involvement from all stakeholders and strengthening government accountability.

15. Increase public awareness by improving communications about air pollution. Regular and accurate information on the severity of air pollution and its associated health impacts should be made available to the people of Ulaanbaatar. Good sources of information exist and this information should be disseminated more widely. This could include enhancing and making more regular the warnings on air pollution levels in different parts of the city as well as regularly monitoring air pollution levels in key public spaces, such as hospitals and schools. Awareness campaigns should be implemented to help inform the public about effective strategies to mitigate the effects of pollution, for example, specifying situations when air pollution masks are required and what type of masks should be used. Improving the understanding of the link between outdoor and indoor air pollution is another important area that should be targeted through awareness campaigns.

\section{Strengthen the analytical approach to understanding the impact of pollution and identify} corrective actions. Policymakers and other stakeholders do not share a common understanding of the effectiveness of different policies available to tackle air pollution in Mongolia. A robust assessment of available policy options, based on analytical research, would provide an invaluable tool for policymakers to identify the most cost-effective solutions and to allocate budget resources accordingly. Clearly defined policies would help parliamentarians and the public hold policymakers to account. Authorities should therefore look to expand research on the impacts of air pollution by, for instance, developing research programs focusing on air quality management.

17. Establish standards and certification for health protection measures. There is insufficient public knowledge among Mongolians of the mitigating measures for air pollution. This means that residents, particularly those in Ulaanbaatar, often do not take mitigating actions or use such measures inappropriately. Basic standards, based on international protocols, should be established for protection measures in Mongolia, including air masks, monitors, air purifiers, etc. In addition, a certification process should be introduced to ensure that consumers can easily identify which pollution-mitigating products meet the required standards.

18. Step up efforts to reduce burning of raw coal and solid waste. Efforts to incentivize the use of more environment-friendly fuels to a sustainable level should become a policy priority. While the Government of Mongolia's ban on the use of raw coal in Ulaanbaatar from May 2019 is a good start, more work is needed to establish mechanisms for the procurement and distribution of clean coal to encourage the private sector to enter the clean-coal market. This will reduce the need for subsidies and ensure adequate storage and distribution channels. For maximum impact, efforts to introduce loweremitting stoves, as well as electric stoves, need to be continued in parallel with incentives on cleaner sources of heating. 


\section{Observations and Suggestions}

\section{Ажиглалт ба санал}

19. Classify polluting products by level of emissions. Behavioral change is needed to curb air pollution in Ulaanbaatar over the long-term and this will require changes to incentives to encourage the use of cleaner fuel or lower-emitting stoves. The government should therefore introduce regulatory changes to classify pollution-emitting products, such as stoves or fuel, based on emission levels. This is a prerequisite to levying higher taxes on the import of poor-quality transport fuel and reducing taxes on cleaner fuels. It is important for government inspection agencies to enforce existing legal clauses for licenses to operate, for permitted emission levels, and for polluter-pays principles for the main sources of pollution.

20. Incentivize the development of new technologies and strategies. Finding long-term solutions to air pollution will be facilitated by a mix of new technologies and strategies. These solutions will involve affordable housing options, energy and heating infrastructure provision, and improving the affordability of mitigation measures such as cleaner coal and electric stoves. These solutions need to be part of longterm policy actions, but it is key that technologies and strategies are developed and tested now. Doing so will ensure that there is clear evidence on the effectiveness of different approaches when urban development planning requires housing or energy solutions to be scaled up. These technologies and strategies need to be financed now, and the government, the private sector, and development partners should join in finding ways to finance initial efforts, laying the foundations to attract funding for scaling up of appropriate technologies at a future point.

\section{b. Long-Term Policy Actions}

21. Redevelop urban areas and align urban planning with environmental targets. Sustainable solutions to environment pollution require a redevelopment of urban areas, part of which will ensure that people have access to good quality shelter and cleaner sources of energy, heating, and sanitation. Ongoing efforts for urban development in Ulaanbaatar need to be scaled up beyond existing focus subcenters, to ensure broader access to essential services across ger areas. Environmental issuesmost notably air pollution, but also soil and water pollution-need to be put at the forefront of urban development plans.

22. Promote livelihood opportunities in rural areas to reduce migration to cities. The best way to reduce the pressure of urbanization is to ensure that economic opportunities exist for those residing in rural areas of Mongolia. Provincial development plans have to be prepared in coordination with national development strategies, based on the comparative advantage of each province to generate economic growth and employment opportunities. This approach, although complex, is more effective than legislating to restrict migration to the cities, a policy that is difficult to monitor and enforce, particularly if people are leaving rural areas due to limited economic opportunities.

23. Strengthen institutional capacity. Sustainably curbing air pollution in Mongolia requires an increase in implementation and enforcement capacities at all levels of the country's administration. It 


\section{Winning the Fight Against Air Pollution in Ulaanbaatar \\ Улаанбаатар хотын агаарын бохирдлын эсрэг тэмцэлд ялах нь}

also requires strong monitoring capacity through improved collection and analysis of key data, which are essential to formulating new policies and regulations to sustain pollution reduction efforts. Achieving stronger monitoring will require a combination of training, capacity building, procuring better equipment, and using technology to create and manage online data management systems.

24. Develop sustainable transport plans. Although transport is not the major cause of air pollution in Ulaanbaatar, as urban redevelopment occurs and urban areas become more economically dynamic, the demand for transport services will increase. It is essential to develop urban transport systems that can efficiently cope with this increasing demand, without creating further air pollution. Policy actions could promote the provision of cleaner fuel in accordance with emission standards for cleaner engines, improved public transport to reduce the use of private cars, car-pooling, and restricted traffic areas.

25. Develop long-term energy solutions for urban areas. Ulaanbaatar has growing energy and heating needs. Energy solutions that can cope with future demand should be developed now and be closely aligned with Mongolia's environmental targets. Urban redevelopment will require energy solutions for the ger areas, including connecting these areas to reliable and clean energy and heating sources. In this context, adding new electricity and heat-generation capacity in Ulaanbaatar is critical to meeting the established policy target in 2025 . One approach would be to develop cutting-edge combined heat and power plants to optimally supply affordable electricity and heating. Distributed renewable energy systems, i.e., geothermal with solar thermal and storage solutions, should also be tested for possible deployment in areas where extending the district heating system is uneconomical. 


\section{Observations and Suggestions}

\section{Ажиглалт ба санал}

\section{I. Ерөнхий зүйл}

1. Агаарын бохирдлыг улам бүр эрчимжиж буй үйлдвэржилтийн төлөөс хэмээн хүлээж авах нийтлэг хандлага бий. Гэтэл их хэмжээний бохирдолд удаан хугацаагаар өртсөн иргэд эрүүл мэндээрээ хохирохын зэрэгцээ ажил хөдөлмөр эрхлэх, орлого олох боломжоо алддаг нь нийгэм-эдийн засгийн асар их үр дагаврыг араасаа дагуулдаг. Эдгээр асуудлуудыг шийдвэрлэхэд бодит шинэчлэл, бодлогын алхмуудаар дэмжигдсэн, олон нийтийг хамарсан, харилцан уялдаатай үйл ажиллагааг авч хэрэгжүүлэх зайлшгүй шаардлагатай.

2. Улаанбаатар хотын агаарын бохирдол аюултай түвшинд хүрээд байна. Хөдөөгөөс хот руу чиглэсэн хүн амын шилжилт хөдөлгөөнийг зохицуулах хот төлөвлөлт байхгүй байгаа нь асуудлын гол шалтгаан юм. Үр дагавар нь эрүүл мэндийн сөрөг нөлөөллөөс нэгэнт хальж улс орны хөгжлийн томоохон сорилтыг бий болгожээ. Үүний нэг жишээ нь, 2013 онд агаарын бохирдлоос үүдэлтэй нийгмийн халамжийн зардал тухайн жилийнхээ ДНБ-ний 6.9 хувьтай тэнцсэн байна. ${ }^{1}$

3. Нийслэлийн хүн ам 2025 онд 1.9 сая, 2050 онд 2.7 сая болж өсөх тооцоо байдаг. Шийдэмгий арга хэмжээ цаг алдалгүй авахгүй бол бохирдол болон түүнээс гарах хохирол ноцтой түвшинд хүрэх аюул нүүрлээд байна. Улаанбаатар хотын агаарыг бохирдуулж буй гол хүчин зүйлст дүн шинжилгээ хийсний үндсэн дээр агаарын бохирдлын эсрэг тэмцэх цогц шийдлийг боловсруулахтай холбогдох бодлогын зөвлөмжүүдийг энэхүү баримт бичигт толилууллаа.

\section{II. Улаанбаатар хотын агаарын бохирдол ба бодлогын сорилт}

4. Өвлийн улиралд Улаанбаатар хот дэлхийн хамгийн хүйтэн бөгөөд бохирдол ихтэй нийслэл хот болдог. Өвлийн саруудад $\mathrm{PM}_{2.5}$ буюу нарийн ширхэглэгт тоосонцрын жилийн дундаж агууламж зөвшөөрөгдөх хэмжээнээс 40 дахин өндөр байдаг бол зарим өдрүүдэд 80 дахин өндөр байх тохиолдлууд ч гарсаар байна. ${ }^{2}$ Энэ бохирдлын түвшинд хүний болон байгалийн хүчин зүйлс нөлөөлж байгаа юм. Ган, зудын давтамж нэмэгдсэн нь хөдөөгийн малчдын амьдрах орчин нөхцлийг хүндрүүлж, хот суурин газар бараадахад хүргэж байгаа бөгөөд үүний дүнд Улаанбаатар хотын хүн ам 2007 оноос хойш 30 хувиар өсөж 1.5 саяд хүрчээ. Шинээр шилжин ирэгсдийг зохистой шингээхүйц хот төлөвлөлт дутагдсанаас томоохон талбайг хамрах гэр хорооллууд үүсэн бий болсон. Өнөөдөр нийслэлийн нийт хүн амын 60 хувь буюу 800,000 хүн гэр хороололд оршин сууж байна.

\footnotetext{
1 Дэлхийн банк. 2016. Агаарын бохирдлын өртөг: Зайлшгүй авах арга хэмжээний эдийн засгийн үндэслэлийг нотлох нь. Вашингтон хот.

$2 \mathrm{PM}_{2.5}$ гэдэг нь 2.5 микрометр хүртэлх диаметртэй нарийн ширхэглэгт тоосонцрыг хэлнэ.
} 


\section{Winning the Fight Against Air Pollution in Ulaanbaatar}

Улаанбаатар хотын агаарын бохирдлын эсрэг тэмцэлд ялах нь-

5. Гэр хороололд цэвэр бохир ус, нийтийн тээвэр, дулаан хангамж, гэрэл цахилгаан зэрэг нийтийн аж ахуйн суурь үйлчилгээ дутмаг байна. Гэр хорооллын оршин суугчид орон гэрээ халаах болон хоол хүнсээ бэлтгэх зорилгоор түүхий нүүрс (ядуу өрхүүдийн хувьд хатуу хог хаягдал) түлдэг. Энэ галлагаанаас гарч буй $\mathrm{PM}_{2.5}$ нь өвлийн улиралд нийт нарийн ширхэглэгт тоосонцрын ялгарлын 80 хувийг бүрдүүлж байна. Үлдсэн 20 хувийг гэр хороолол дахь хуучин уурын зуухнууд, замын түгжрэл үүсгэгч тээврийн хэрэгслүүд, насжилт өндөртэй дулааны цахилгаан станцууд, шороон замаас дэгдэх тоос, нүүрсний дэгдэмхий бодис зэрэг бүрдүүлдэг. Үүний зэрэгцээ өвлийн улиралд тохиох агаарын инверцийн үзэгдэл нь (газрын гадаргууд ойр орших дулаан агаарын давхарга хүйтэн агаарын давхаргатай харших үзэгдэл) нийслэл хотын байрлах хөндийд агаарын давхаргыг тогтоож, бохирдол сарнин замхрах боломжийг хязгаарладаг байна.

6. Хүн амын эмзэг бүлгүүд агаарын бохирдлын сөрөг нөлөөнд хамгийн ихээр өртөж байна. Ядуу иргэд гол төлөв бохирдол ихтэй дүүргүүдэд ажиллаж амьдардгийн дээр шим тэжээлтэй хоол хүнс, эмнэлгийн тусламж үйлчилгээ авч чаддаггүйгээс бохирдлын нөлөөг хамгийн түрүүнд мэдэрдэг. Мөн хүүхэд нялхаст хүндээр тусч буйг ургийн өсөлт хөгжил удаашрах, хүүхэд дутуу төрөх, хатгаа, тархины хөгжлийн саатал, амьсгалын замын архаг болон цочмог өвчлөлийг үүсгэгч уушгины эмгэг зэрэгт хүүхдүүд ихээр өртөж байгаагаас харж болохоор байна. НҮБ-ийн Хүүхдийн сангаас 2018 онд хийсэн судалгаанд 2009-2011 оны өвөл нярайн эндэгдэл зуны улирлынхаас 3.5 дахин өндөр байсныг дурджээ. ${ }^{3}$ Иргэдийн эрүүл мэндийг төрсөн цагаас нь эхлэн хохироож буй агаарын бохирдлын улмаас өвчлөх, хөдөлмөрийн чадвараа алдах, эрт нас барах зэргээр хөдөлмөрийн бүтээмж буурч, иргэдийн орлого олох боломж хаагдаж байна. НҮБ-ийн Хүүхдийн сангаас хийсэн судалгаагаар агаарын бохирдлоос үүдэлтэй хүүхдийн өвчлөлд 24.8 тэрбум төгрөгийн (9.8 сая ам.доллар) нэмэлт хөрөнгийг 2017-2025 онуудад зөвхөн Улаанбаатар хотод зарцуулах шаардлага үүснэ хэмээн тогтоожээ.

7. Хот төлөвлөлт хангалтгүйгээс үүссэн нөхцөл байдлыг бодлогын тууштай бус алхмууд улам хүндрүүлсэн байх магадлалтай. Жишээлбэл, түүхий нүүрсний хэрэглээнээс үүдэлтэй агаарын бохирдлыг бууруулах бодлогын арга хэмжээнүүдийг шуурхай авч хэрэгжүүлсэн ч туршилтыг хэт жижиг хүрээнд хийсний улмаас үр дүнгүй болж, цааш нь үргэлжлүүлэх боломжгүй болсон. Цахилгаан эрчим хүчний тарифын хөнгөлөлт ч мөн цахилгаан халаагуур худалдан авалтыг дэмжих санхүүгийн механизмгүйгээр нүүрснээс татгалзах хөшүүрэг болохуйц бодлогын алхам болж чадаагүй юм. Сэргээгдэх эрчим хүчийг дэмжих урт хугацааны тарифийн асуудлаар бүрэн зөвшилцөлд хүрээгүй, мөн энэ чиглэлээр техникийн чадавх сул байгаагаас сэргээгдэх эрчим хүчийг түлхүү ашиглах боломж хязгаарлагдаж байна. Мөн агаарын бохирдлыг бууруулахад өндөр нөлөө үзүүлэх нь тогтоогдсон хэдий ч

\footnotetext{
НҮБ-ийн Хүүхдийн сан. 2018. Монгол улсын агаарын бохирдлын хямрал: Хүүхдийн эрүүл мэндийट хамгаалах тухай уриалга. Улаанбаатар.
} 


\section{Observations and Suggestions}

\section{Ажиглалт ба санал}

эхний туршилтууд амжилтгүй болсноос байгальд ээлтэй сайжруулсан зуух болон цэвэр түлшний хэрэглээг тууштай дэмжээгүй юм.

8. Гэхдээ шинэ батлагдсан хуулийн хүрээнд зарим ахиц дэвшил гарсан. Агаарын тухай хуульд халаалтын зориулалттай цахилгаан эрчим хүчний хэрэглээнд иргэдэд татаас олгох, түүхий нүүрсийг оруулахыг хориглох зэрэг чухал арга хэмжээг хуульчлан заасан байна. Энэхүу хуулиар Агаарын бохирдлыг бууруулах үндэсний хороог байгуулах үүргийг Ерөнхий сайдад хүлээлгэж, Цэвэр агаарын санг байгуулах эрхийг Засгийн газарт олгосон. Агаарын бохирдлын төлбөрийн тухай хуулиар агаар бохирдуулсны төлбөр төлөх тогтолцоог мөн нэвтрүүлээд байна. Эдгээр санаачилгууд нь бохирдуулагч бодисын хэмжээ хязгаарыг тогтоож, бохирдуулагчид хяналт тавьж төлбөр ногдуулдаг тогтолцоог бүрдүүлэх зорилготой байв. Гэвч бодлогын хэрэгжилт сул, бодлого тогтвортой бус, агаарын бохирдол улам нэмэгдсэн, мөн эдийн засгийн нөхцөл байдал 2015-2016 онуудад хүндэрсэн зэрэг нь агаарын бохирдлын эсрэг илүү шийдэмгий тэмцэж, бохирдлыг бууруулах хүчин чармайлтыг илүү хариуцлагатай болгохыг Засгийн газраас шаардсан олон нийтийн хөдөлгөөн өрнөхөд хүргэжээ. Үүний хариуд Засгийн газар 2016 оны 11-р сард Үндэсний хороог сэргээн байгуулсан байна. Тус хороо 2017-2025 онд хэрэгжих 9.8 их наяд төгрөг буюу 4.5 тэрбум ам.долларын төсөв бүхий Агаар болон орчны бохирдлыг бууруулах үндэсний хөтөлбөрийг боловсруулах ажлыг удирдан чиглүүлсэн бөгөөд хөтөлбөр 2017 оны 3-р сард батлагджээ. Цогц хөтөлбөрийг боловсруулан баталсан явдал нь сайн эхлэл хэдий ч түүний хэрэгжилтийг хангахад ихээхэн хүчин чармайлт шаардлагатай байна. Өөрөөр хэлбэл, Засгийн газар улс төрийн мөчлөгөөс үл хамааран урт хугацаанд тогтвортой ажиллаж байж уг хөтөлбөр үр дүнгээ өгөх юм.

\section{III. Бусад улс орнуудын туршлага}

9. Бодлогын тодорхой алхмууд болон Засгийн газрын идэвхтэй оролцооны дүнд бохирдлын хяналт амжилттай хэрэгждэгийг олон улсын туршлага харуулж байна. Олон нийтийн мэдлэг ойлголт, иргэдийн шахалт дарамт нь засгийн газрын хариуцлагыг бэхжүүлэхэд чухал үүрэг гүйцэтгэдэг. Жишээлбэл, 1970-аад онд АНУ-д агаарын бохирдлыг бууруулахад чухал нөлөө үзүүлсэн Байгаль хамгаалах алба байгуулагдаж, Цэвэр агаарын тухай хууль батлагдахад байгаль хамгаалах чиглэлээр үйл ажиллагаа явуулдаг төрийн бус байгууллагууд голлох үүргийг гүйцэтгэж байв.

10. Зарим улс орнууд бохирдлыг ихээр үүсгэгч авто машины болон түлшний хэрэглээг бууруулахад чиглэсэн хөшүүрэг бүхий хууль эрх зүйн орчныг амжилттай бүрдүүлсэн байдаг. Энэхүу арга нь боломжийн өртгөөр орлуулах хувилбарт сонголт, шаардлагатай өөрчлөлтийг хүлээж авахад бэлэн олон нийтийн мэдлэг ойлголт, засгийн газрын тогтвортой бодлого, тууштай үйл ажиллагаанд тулгуурлан хэрэгжүүлсэн тохиолдолд бодитой үр дүнд хүрдэг болохыг олон улсын туршлага харуулдаг. Ирланд улсын Дублин хотод "Утаат нүүрсийг хориглох тухай хууль”-ийг 1990 онд батлан хэрэгжүүлж эхэлсэн бөгөөд үр дүнд 


\section{Winning the Fight Against Air Pollution in Ulaanbaatar}

Улаанбаатар хотын агаарын бохирдлын эсрэг тэмцэлд ялах нь-

нь 8,000 дутуу төрөлтөөс урьдчилан сэргийлж чадсан байна. ${ }^{4}$ Энэ туршлага дээрээ үндэслэн Ирландын засгийн газар “агаарын чанарыг сайжруулах бүсүүд"-д нүүрс болон зарим түлшийг хориглох тухай шийдвэрийг мөн гаргаж байв. Ингээд хоригийг орон даяар хэрэгжүүлэх тухай шийдвэрийг 2017 оны 12-р сард гаргасан бөгөөд нүүрс түгээгчдэд үлдэгдэл нөөцөө борлуулах боломжийг олгох үүднээс 2019 оноос хүчин төгөлдөр болгохоор шийдвэрлэсэн байна.

11. Агаар бохирдуулагч хорт бодисуудыг технологи ашиглан хязгаарласан тод жишээг Германы туршлагаас харж болно. Хамгийн цэвэр цахилгаан станцтай улсад тооцогддог тус улсын эрчим хүчний салбар шатдаг түлшнээс хамааралтай хэвээр байгаа ч агаарын бохирдлын эсрэг тэмцлийг тус улс түүчээлж байгаа билээ. Герман улс болон Их Британи Умард Ирландын Нэгдсэн вант улс нь түлшний хатуу хяналтын тогтолцоог 1980-аад онд нэвтрүүлсний үр дүнд (хар тугалгагүй болон хүхрийн нэн бага агууламжтай түлш) тээврийн хэрэгслээс үүдэлтэй агаарын бохирдлыг үлэмж хэмжээгээр бууруулж чадсан байна.

12. Олон нийтийн хүчтэй шахалтаар Засгийн газраас шийдэмгий авч хэрэгжүүлсэн арга хэмжээгээр тодорхойлогдох БНХАУ-ын арга барилыг харахад сургамжтай зүйл их байна. Хэрэгжихүйц, зорилтот арга хэмжээнүүдийг боловсруулан, шинжлэх ухааны үндэслэлтэй судалгаа шинжилгээнд үндэслэн бохирдлыг ойлгож, бэрхшээлийг тодруулахад хөрөнгө санхүу харамгүй зарцуулжээ. Эрх бүхий байгууллагуудын хийсэн дүн шинжилгээнд үндэслэн өртөг зардал нэлээд өндөр хэдий ч үр дүнтэй алхмуудыг тодорхойлж, үндэсний хэмжээний томоохон хөтөлбөрт тусгасан байдаг. Үүнд, нүүрсний хэрэглээнд хязгаар тогтоох, гангийн үйлдвэрлэл зэрэг үндэсний томоохон үйлдвэрүүдийн бүтээгдэхүүний хэмжээнд хяналт тавих зэрэг заалтууд тусгагдсан байна. Засгийн газрын хүчин чармайлт, манлайлал нь бодлогын хэрэгжилтэд хамгийн том түлхэц болсон байдаг. Эдгээр хүчин чармайлт оргилдоо хүрч, эхний гарсан амжилтуудаа бодит болгох, авч хэрэгжүүлсэн арга хэмжээгээ үргэлжлүүлэхэд институцийн төвшинд дэмжлэг үзүүлэх зорилгоор 2018 оны 3-р сард байгаль орчны “хүчирхэг” яамыг үүсгэн байгуулсан байна.

\section{IV. Зөвлөмжүүд}

13. Дээр дурдсан сургамж туршлагуудаас авах зүйл их бий ч хөдөөгөөс хотыг зорих хүн амын шилжилт хөдөлгөөн эрчимтэй явагдаж байгаа, тэсгим хүйтэн өвлийн улиралтай Монгол улсын хувьд тулгарч буй сорил бэрхшээл нь нэлээдгүй өвөрмөц тул тэрхүү онцлогт нийцсэн арга хэмжээнүүдийг хэрэгжүүлэх шаардлагатай. Тэдгээр арга хэмжээнүүд нь Засгийн газрын тууштай манлайлал дор олон нийт, иргэний нийгмийн байгууллагууд,

\footnotetext{
$\overline{4}$ Ирланд улсын Засгийн газар. Харилцаа холбоо, уур амьсгалын арга хэмжээ, байгаль орчны газар. Утаат нүүрсийг хориглох тухай хууль. https://www.dccae.gov.ie/en-ie/environment/topics/air-quality/smoky-coal-ban/Pages/ default.aspx (2018 оны 9 дүгээр сард хандсан).
} 


\section{Observations and Suggestions}

\section{Ажиглалт ба санал}

хувийн хэвшил, хөгжлийн түншүүд зэрэг олон оролцогчдын харилцан уялдаатай, тогтвортой хүчин чармайлтын дүнд амжилттай хэрэгжих боломжтой. 2020 он хүртэл богино хугацаанд авч хэрэгжүүлэх арга хэмжээнүүд нь агаарыг бохирдуулагч гол үүсвэрүүдийг цөөлөх, бохирдлоос үүдэж буй өвчлөлийг бууруулах зэрэгт чиглэвэл зохилтой. Харин 2030 он хүртэлх урт хугацааны арга хэмжээний хүрээнд агаарын чанарыг тогтвортой сайжруулах асуудалд анхаарах нь чухал юм. Урт болон богино хугацааны бодлогыг боловсруулах, төлөвлөх, төсөвлөх нь амар хийгдэх ажил биш ч амжилттай хэрэгжүүлсэн тохиолдолд Монгол Улсын бүтээмжийг тогтвортой өсгөж, ирээдүйн хөгжил цэцэглэлтийг тодорхойлох эдийн засгийн идэвхитэй хот суурин газруудын үндэс суурийг тавих юм. Монгол Улсын Засгийн газар олон тооны зөв зүйтэй алхмыг авч хэрэгжүүлж буйн тод жишээ нь Улаанбаатар хотод хэрэглэгдэх түлшний чанарыг дээшлүүлэх, агаарын чанарыг сайжруулахтай холбогдох хууль эрх зүйн орчинг боловсронгуй болгох тал дээр АХБ-наас өгсөн зөвлөмжийг хэрэгжүүлэхэд өндөр ач холбогдол өгч байгаа явдал юм. ${ }^{5}$ Түүнчлэн, асуудлыг шийдвэрлэхэд шаардлагатай дэмжлэг туслалцааг бусад олон хөгжлийн түншүүд үзүүлсээр байна. Гаргасан амжилтаа ахиулж, илүү ихийг хийх боломж байгааг харгалзан дараах зөвлөмжүүдийг өгч байна. Үүнд:

\section{а. Богино хугацааны бодлогын арга хэмжээнүүд}

\section{4. Бохирдлыг бууруулахад чиглэсэн бодлогын арга хэмжээнд хяналт тавих} оролцогч талуудын санаачлагыг бий болгох. Агаарын бохирдлыг бууруулах үндэсний хороо нь агаарын чанарт эерэг нөлөө үзүүлэх гол арга хэмжээнүүдийг хэрэгжүүлэх эрх мэдэлтэй байх хэрэгтэй. Учир нь агаарын бохирдлыг бууруулахад олон жилийн туршид тогтвортой, тууштай, харилцан уялдаатай ажиллах шаардлагатай байдаг тул улс төрийн түвшинд талууд бүрэн зөвшилцөлд хүрэх нь нэн чухал юм. Ингэж чадвал улс төрийн ямар хүчин эрх барьж байгаагаас үл хамааран агаарын бохирдолтой тогтвортой бөгөөд тууштай тэмцэх баталгаа үүснэ. Үүний тулд Засгийн газрын зүгээс Үндэсний хорооны шийдвэрийн хэрэгжилтийг хянах, уялдааг хангах, зохих хяналтыг тавих чиг үүрэг бүхий улс төрөөс хараат бус ажлын албыг байгуулах хэрэгтэй гэж үзэж байна. Түүнчлэн, бодлогын залгамж чанарыг үргэлжлүүлэх үүднээс тухайн ажлын алба нь агаарын бохирдлыг бууруулах чиглэлээр авч хэрэгжүүлсэн арга хэмжээнүүдийг дэс дараалан бүртгэж, баримтжуулан хадгалах үүрэгтэй байвал зохино. Тус ажлын албанд бодлого тодорхойлогчид, иргэний нийгмийн байгууллагууд, сэтгүүлчид, хувийн хэвшлийн төлөөлөл зэрэг талуудыг байлцуулснаар бүх талын оролцоог ханган, дэмжлэгийг авч, Засгийн газрын хүрээнд хариуцлагын тогтолцоог бэхжүүлэх боломжтой болох юм.

\footnotetext{
5 АХБ. 2018. Улаанбаатар хотын агаарын чанарыट сайжруулах хөтөлбөр. Манила хот.
} 


\section{5. Агаарын бохирдлын талаарх мэдээлэл сурталчилгааг эрчимжүүлснээр олон} нийтийн ойлголтыг нэмэгдүүлэх. Агаарын бохирдлын бодит түвшин болон эрүүл мэндэд үзүүлэх сөрөг нөлөөллийн талаарх үнэн зөв мэдээллийг Улаанбаатар хотын иргэдэд тогтмол өгч байх хэрэгтэй. Баталгаат эх сурвалжуудаар дамжуулан мэдээллийг илүү өргөн хүрээнд түгээхэд анхаарах нь чухал. Энэ ажлын хүрээнд хотын тодорхой байршлуудад агаарын чанар ямар байгаа талаар тогтмол сануулга анхааруулга цацах, мөн эмнэлэг, сургууль зэрэг олон нийтийн газруудын агаарын бохирдлын хэмжээг тогтмол хянах зэрэг ажлуудыг хийж болох юм. Агаарын бохирдлоос үүдэх хор хохирлыг сааруулах үр дүнтэй арга замыг иргэдэд мэдээлэх, жишээ нь, амны маскны ач холбогдол, маскны сонголт зэрэг асуудлаар иргэдийн мэдлэг ойлголтыг дээшлүүлэх кампанит ажил хийх хэрэгтэй. Мөн дотор болон гадна орчны агаарын бохирдлын уялдаа холбооны талаар иргэдийн мэдлэг ойлголтыг бэхжүүлэх нь кампанит ажлын бас нэгэн чухал чиглэл байж болох юм.

\section{6. Агаарын бохирдлын үзүүлж буй нөлөөлөлд дүн шинжилгээ хийх аргачлалыг} сайжруулах, нөлөөг бууруулах, түүнээс зайлсхийх үр дүнтэй арга хэрэгслийг тодорхойлох. Монгол улсад агаарын бохирдлын эсрэг хэрэгжүүлж болох төрөл бүрийн бодлогууд хэр үр дүнтэй байх талаар бодлого тодорхойлогчид болон бусад оролцогч талууд нэгдмэл ойлголтгүй байна. Боломжит бодлогын арга хэмжээнүүдийг дүн шинжилгээнд тулгуурлан бодитойгоор үнэлснээр шийдвэр гаргагчид өртөг зардлын хувьд хамгийн үр ашигтай шийдлүүдийг тодорхойлж, холбогдох төсвийн хуваарилалтыг хийх боломжтой болох юм. Энэ нь хууль тогтоогчдод дөхөм болоод зогсохгүй бодлого тодорхойлогчдоос хариуцлага нэхэх боломжийг олон нийтэд олгоно. Тиймээс агаарын чанарын удирдлагын асуудлаар судалгаа шинжилгээний хөтөлбөр боловсруулах зэргээр агаарын бохирдлын нөлөөллийн судалгааг өргөжүүлэхэд анхаарах нь чухал байна.

\section{7. Эрүүл мэндийг хамгаалахад чиглэсэн үйл ажиллагаанд стандарт тогтоож,} гэрчилгээжүүлэх. Агаарын бохирдлын сөрөг нөлөөг бууруулах арга хэрэгслийн талаарх олон нийтийн мэдлэг, ойлголт сул байна. Өөрөөр хэлбэл, Улаанбаатар хотын оршин суугчид сөрөг нөлөөг бууруулах арга хэрэгслийг хэрэгжүүлдэггүй, аль эсвэл буруу хэрэглэдэг гэсэн үг юм. Амны маск, бохирдлыг хянах төхөөрөмж, агаар цэвэршүүлэгч зэрэг хамгааллын арга хэрэгслүүдийн талаар суурь стандартуудыг олон улсын хэм хэмжээнд тулгуурлан боловсруулах хэрэгтэй. Мөн түүнчлэн, бохирдлын нөлөөнөөс хамгаалах бараа бүтээгдэхүүн холбогдох норм стандартыг хангаж байгаа эсэхийг хэрэглэгчдэд тодорхой харуулах гэрчилгээжүүлэлтийн системийг нэвтрүүлэх асуудлыг судалж үзэх нь чухал.

\section{8. Түүхий нүүрс болон хатуу хог хаягдал шатаах үйл ажиллагааг хязгаарлах.}

Байгальд ээлтэй түлшний хэрэглээг тогтвортой түвшинд хөхиүлэн дэмжих хүчин чармайлтыг бодлогын тэргүүлэх чиглэл болгох нь чухал байна. 2019 оны 5-р сараас Улаанбаатар хотод түүхий нүүрс түлэхийг хориглох шийдвэр гаргасан нь сайшаалтай эхлэл бөгөөд цаашлаад цэвэр нүүрсний худалдан авалт, түгээлтийн механизмыг бий болгох замаар цэвэр нүүрсний зах зээлд хувийн хэвшлийг татан оролцуулах хэрэгтэй. Энэ 


\title{
Observations and Suggestions
}

\author{
Ажиглалт ба санал
}

нь эргээд хөнгөлөлт татаас олгох шаардлагыг бууруулж, хангалттай хэмжээний түлшийг агуулах болон түгээх сувгуудыг үүсгэн бий болгох юм. Үүний зэрэгцээ, сайжруулсан болон цахилгаан зуухыг нэвтрүүлэх ажлыг зэрэг явуулснаар үр нөлөөг хамгийн өндөр түвшинд хүргэх боломж бүрдэнэ.

\section{9. Хорт бодис ялгаруулах хэмжээгээр нь бохирдуулагч бараа бүтээгдэхүүнийг} ангилах. Агаарын бохирдлыг бууруулж, гаргасан амжилтаа урт хугацаанд хадгалахад зан үйлийн өөрчлөлт зайлшгүй шаардлагатай бөгөөд үүний тулд цэвэр түлш, аль эсвэл ялгаруулалт багатай зуухны хэрэглээг дэмжин хөшүүрэгдэх өөрчлөлтийг хийх хэрэгтэй. Үүний тулд Засгийн газраас бохирдлын эх үүсвэрүүд (зуух, түлш г.м.)-ийг ялгаруулалтын түвшнээр нь ангилах зохицуулалтыг нэвтрүүлвэл зохино. Энэ нь улмаар тээврийн салбарт чанар муутай түлш нийлүүлэгч илүү өндөр татвар төлдөг, цэвэр түлш нийлүүлэгчид хөнгөлөлт эдэлдэг гэх мэт практик үр дагавар бүхий алхмуудын урьтал болох юм. Бизнесийн үйл ажиллагаа явуулах тусгай зөвшөөрөл, агаар бохирдуулагч бодисын зөвшөөрөгдөх хэмжээ, “бохирдуулагч нь төлөх" зарчим зэрэгтэй холбоотой хууль тогтоомжийн хэрэгжилтийг ханган ажиллах нь төрийн хяналтыг хэрэгжүүлэгч байгууллагуудын хувьд чухал.

20. Шинэ технологи нэвтруүлэлтийг дэмжих. Шинэ технологи, шилдэг стратегийн бүрдэл нь агаарын бохирдлыг бууруулах урт хугацааны шийдлүүдийг тодорхойлоход дэмжлэг болно. Эдгээрт төлбөрийн чадварт нийцсэн орон сууцны хангамжийг сайжруулах, цахилгаан халаалтын дэд бүтцийг хүртээмжтэй болгох, цэвэр нүүрс, цахилгаан зуух гэх мэт бохирдлыг бууруулах арга шийдлүүдийг дурьдаж болно. Эдгээр шийдлүүдийг урт хугацааны бодлогод тусгахаас гадна технологи, стратегийг нь одоо нэвтрүүлж, туршиж үзэх нь туйлын чухал. Ингэснээр хот төлөвлөлт, байгуулалтын явцад орон сууц, эрчим хүчний шийдлүүдийг өргөн хүрээнд хэрэгжүүлэх боломж бүрдэх үед олон төрлийн хувилбаруудын аль нь илүү үр ашигтай болохыг урьдчилан тодорхойлж, нотолсон байх юм. Ийм санал санаачлага, технологиуд санхүүжилт шаардах тул Засгийн газар, хувийн хэвшил, хөгжлийн түншүүд эхний ээлжинд шаардлагатай хөрөнгө оруулалтыг шийдвэрлэх, ирээдүйд өргөжүүлэн хэрэгжүүлэх үндэс суурийг тавих тал дээр хамтран ажиллах нь чухал юм.

\section{b. Урт хугацааны бодлогын арга хэмжээнүүд}

\section{1. Хот суурин газрыг дахин төлөвлөж, хот байгуулалтыг байгаль орчны} зорилтуудтай уялдуулан хэрэгжүүлэх. Орчны бохирдлыг бууруулах тогтвортой шийдлүүд нь хот суурин газрыг дахин төлөвлөхийг шаардах бөгөөд үүний дүнд иргэд байгальд ээлтэй цэвэр цахилгаан, дулаан, ариутгах татуурга бүхий чанартай орон байранд орох боломжтой болох юм. Улаанбаатар хотод хэрэгжих төсөл хөтөлбөрүүдийг өнөөгийн дэд төвүүдээр хязгаарлахгүйгээр өргөжүүлэн тэлж, гэр хорооллыг нийтийн аж ахуйн суурь үйлчилгээнд өргөнөөр хамруулахад анхаарах нь чухал байна. Агаарын бохирдол төдийгүй хөрс, усны 


\title{
Winning the Fight Against Air Pollution in Ulaanbaatar
}

Улаанбаатар хотын агаарын бохирдлын эсрэг тэмцэлд ялах нь-

бохирдол зэрэг орчны бохирдлын хүчин зүйлсийг хот байгуулалт, төлөвлөлтийн түлхүүр асуудал болгон авч үзэх нь чухал.

\begin{abstract}
22. Хөдөө орон нутагт амьдрах боломжийг дээшлүүлж, хүн амын шилжилт хөдөлгөөнийг бууруулах. Хотжилттой холбоотой үүсэн бий болж буй дарамтыг бууруулах хамгийн найдвартай арга бол хотод байгаа эдийн засгийн боломж бололцоог хөдөө орон нутагт бүрдүүлэх явдал юм. Үүний тулд хөдөөгийн хөгжлийн бодлого төлөвлөлтийг үндэсний хөгжлийн стратегитай нийцүүлэн боловсруулах, ингэхдээ ажлын байр, эдийн засгийн өсөлт бий болгох тухайн орон нутгийн харьцангуй давуу талыг харгалзах нь чухал. Энэ арга шийдэл нь хэдийгээр илүү ярвигтай, амаргүй боловч шилжилт хөдөлгөөнийг шууд хязгаарлах арга замаас илүү үр дүнтэй хэмээн үзэж байна. Иргэд эдийн засгийн шалтгаанаар шилжин суурьшиж буй нөхцөлд шилжилт хөдөлгөөнийг хязгаарлах шийдвэрийг хэрэгжүүлэх, хэрэгжилтэд хяналт тавихад хүндрэлтэй юм.
\end{abstract}

23. Институцийн чадавхийг бэхжүүлэх. Төр захиргааны бүхий л түвшинд хэрэгжилтийг хангах чадавхи бэхжиж гэмээнэ агаарын бохирдлыг тогтвортой бууруулах зорилт биелэх боломж бүрдэнэ. Түүнчлэн, өгөгдөл мэдээллийг үр дүнтэй цуглуулж, дүн шинжилгээ хийх чадавхийг бэхжүүлснээр бохирдлыг бууруулах хүчин чармайлтыг тогтвортой үргэлжлүүлэх бодлого, зохицуулалтыг шинээр боловсруулах боломжтой болох юм. Сургалт явуулах, чадавхи бэхжүүлэх, илүү сайн тоног төхөөрөмж худалдан авах, цахим мэдээллийн удирдлагын системийг бүрдүүлж, ажиллуулахад шаардагдах технологийг нэвтрүүлэх зэрэг ажлуудыг цогцоор хийснээр хяналтыг сайжруулна.

24. Тогтвортой тээврийн салбарын төлөвлөлтийг хийх. Тээврийн салбар нь Улаанбаатар хотын агаарын бохирдлын гол эх үүсвэр биш хэдий ч хотыг дахин төлөвлөх, хотын эдийн засгийн эрчим нэмэгдэх хэрээр тээврийн салбарын эрэлт хэрэгцээ өсөх нь тодорхой. Тиймээс агаарын бохирдлыг улам дордуулахгүйгээр өсөн нэмэгдэх эрэлтийг бүрэн хангахуйц тээврийн системийг хөгжүүлэх нь чухал. Энэ чиглэлээр хэрэгжих бодлогын хүрээнд хөдөлгүүрийн хорт хийн ялгарлын стандартад нийцсэн цэвэр түлшний хэрэглээ, хувийн автомашины тоог бууруулах нийтийн тээврийн оновчтой систем, автомашины дундын хэрэглээ, хөдөлгөөн хязгаарлах бүсүүд зэрэг олон асуудлыг авч үзэх боломжтой.

25. Хот суурин газрын эрчим хүчний хангамжийн урт хугацааны шийдлүүдийг хөгжүүлэх. Улаанбаатар хотын эрчим хүч, дулааны хэрэгцээ улам бүр өсөж байна. Өсөн нэмэгдэх хэрэгцээг хангах эрчим хүчний хангамжийн шийдлүүдийг урьдчилан боловсруулах, байгаль орчны зорилтуудтай нягт уялдуулах нь туйлын чухал. Хотын дахин төлөвлөлтийн хүрээнд гэр хорооллын эрчим хүчний хангамжийн шийдлүүд, үүний дотор гэр хорооллыг найдвартай бөгөөд цэвэр эрчим хүч болон дулааны эх үүсвэрт холбох асуудлыг шийдвэрлэх шаардлагатай байна. Энэ утгаар цахилгаан эрчим хүчний болон дулааны шинэ эх үүсвэрүүдийг ашиглалтад оруулах нь 2025 оны бодлогын зорилтуудын хэрэгжилтийг хангахад чухал үүргийг гүйцэтгэх болно. Цахилгаан дулааны хамгийн сүүлийн үеийн 


\section{Observations and Suggestions}

\section{Ажиглалт ба санал}

технологи бүхий хосолмол үүсгүүрүүдийг байгуулж, төлбөрийн чадварт нийцэх цахилгаан эрчим хүч, дулаан нийлүүлэх хувилбаруудыг судлан үзэх нь зүйтэй. Төвлөрсөн дулаан хангамжид холбох нь эдийн засгийн үр ашиггүй хэмээн үзэж буй байршлуудад сэргээгдэх эрчим хүчний төвлөрсөн бус хангамж (жишээ нь газрын гүний дулаан, нарны эрчим хүч, хураагуурын хосолмол шийдлүүд) -ийг туршиж, ирээдүйд нэвтрүүлэх боломжийг судлах нь зүйтэй хэмээн үзэж байна. 



\section{Winning the Fight Against Air Pollution in Ulaanbaatar}

This policy note draws on successful experiences of other countries to offer practical recommendations for improving the air quality in Ulaanbaatar and other cities in Mongolia. Urban air pollution is an urgent and serious public health and environmental challenge with enormous socioeconomic costs for Ulaanbaatar. The recommendations provided here acknowledge the existing policy and encourages its translation to an institutionalized framework for sustainable solutions. Designing, planning, and budgeting short- and long-term policies is challenging, but success will result to a significant and sustained boost in productivity and lay the foundations for dynamic urban centers to drive the economic growth of Ulaanbaatar and Mongolia.

\section{Улаанбаатар хотын агаарын бохирдлын эсрэг тэмцэлд ялах нь}

Энэхүү баримт бичиг нь агаарын бохирдлыг амжилттай бууруулсан улс орнуудын туршлага, сургамж дээр үндэслэн Улаанбаатар болон бусад хотуудын агаарын чанарыг сайжруулахад бодитоор хэрэгжүүлэх боломжтой зөвлөмжүүдийг санал болгоно. Агаарын бохирдол нь Улаанбаатар хотын хувьд нийгэм-эдийн засгийн асар өндөр өртөгтэй, эрүүл мэнд, байгаль орчны тулгамдсан асуудал болоод байна. Энд санал болгосон зөвлөмжүүд нь одоо авч хэрэгжүүлж буй бодлогын алхмуудыг хүлээн зөвшөөрч, тогтвортой шийдлүүд бүхий институцийн орчинг бий болгохыг дэмжинэ. Урт болон богино хугацааны бодлогыг боловсруулах, төлөвлөх, төсөвлөх нь амар хийгдэх ажил биш ч амжилттай хэрэгжүүлсэн тохиолдолд Монгол Улсын, тэр дундаа Улаанбаатар хотын бүтээмжийг тогтвортой өсгөж, ирээдүйн хөгжил цэцэглэлтийг тодорхойлох эдийн засгийн идэвхитэй хот суурин газруудын үндэс суурийг тавих юм.

\section{About the Asian Development Bank}

ADB is committed to achieving a prosperous, inclusive, resilient, and sustainable Asia and the Pacific, while sustaining its efforts to eradicate extreme poverty. Established in 1966, it is owned by 67 members - 48 from the region. Its main instruments for helping its developing member countries are policy dialogue, loans, equity investments, guarantees, grants, and technical assistance.

\section{Азийн хөгжлийн банкны тухай}

АХБ нь Ази, Номхон далайн бүс нутагт нэн ядуурлыг арилгах хүчин чармайлтаа үргэлжлүүлэхийн зэрэгцээ цэцэглэн хөгжсөн, хүртээмжтэй, тогтвортой, сөрөг нөлөөнд тэсвэртэй бүс нутгийг цогцлоохын төлөө тууштай ажилладаг. Анх 1966 онд байгуулагдсан тус банкны нийт 67 гишүүн орны 48 нь тухайн бүс нутагт оршдог. АХБ нь бодлогын хэлэлцүүлэг, зээл, өөрийн хөрөнгийн санхүүжилт, батлан даалт, буцалтгүй тусламж болон техникийн туслалцаа зэрэг олон төрлийн арга хэрэгслээр дамжуулан хөгжиж буй гишүүн орнууддаа дэмжлэг үзүүлж байна.

$\mathrm{ADB}$

\section{ASIAN DEVELOPMENT BANK}

6 ADB Avenue, Mandaluyong City 1550 Metro Manila, Philippines www.adb.org

\section{Азийн хөгжлийн банк}

АХБ-ны өргөн чөлөө-6, Мандалуён хот Метро Манила 1550, Филиппин Улс www.adb.org 